DEPARTMENT OF ECONOMICS

OxCarre

Oxford Centre for the Analysis of Resource Rich Economies

Manor Road Building, Manor Road, Oxford OX1 3UQ

Tel: +44(0)1865 271089 Fax: +44(0)1865 271094

oxcarre@economics.ox.ac.uk www.economics.ox.ac.uk

OxCarre Research Paper 21

\title{
Aggressive Oil Extraction and precautionary Saving: Coping with Volatility
}

\author{
Frederick van der Ploeg \\ (OxCarre, University of Oxford)
}




\title{
Aggressive Oil Extraction and Precautionary Saving: Coping with Volatility
}

\author{
Frederick van der Ploeg, University of Oxford ${ }^{1}$
}

\begin{abstract}
The effects of stochastic future oil prices on optimal oil extraction paths and optimal tax, spending and government debt policies are analyzed when demand for oil is linear and preferences quadratic. Without prudence, optimal oil extraction is governed by the Hotelling rule and optimal budgetary policies by the tax smoothing principle. With prudence, the government depletes oil reserves more aggressively and engages in precautionary saving financed by postponing spending and bringing taxes forward, especially if it has substantial monopoly power on the oil market, gives high priority to the public spending target and is very prudent, and future oil demand has high variance. If the oil market is fairly competitive, prudent governments deliberately under-estimate oil reserves and under-predict future oil prices. This leads to less aggressive oil depletion and less government saving. However, if the government attaches high priority to raising public spending to its bliss level, prudence implies a tendency to over-predict future oil prices and reserves which induces more aggressive oil depletion and more government saving. Uncertain economic prospects induce precautionary saving and more aggressive oil extraction.
\end{abstract}

Keywords: Hotelling rule, tax smoothing, prudence, vigorous oil extraction, precautionary saving, taxation and under-spending, oil price volatility, uncertain reserves and economic prospects

JEL codes: D81, E62, H63, Q32

April 2009

${ }^{1}$ OxCarre, Department of Economics, Manor Road, Oxford OX1 3UQ, United Kingdom. Also affiliated with the University of Amsterdam, the Tinbergen Institute, CEPR and CESifo. 


\section{Introduction}

Countries blessed with substantial natural resources face major challenges on how to manage their wealth efficiently. In deciding how much oil to extract today and how much in the future, resource-rich countries rely on the Hotelling rule of optimal extraction (Hotelling, 1931). ${ }^{2}$ This rule requires that one is indifferent between keeping the oil under the ground, on the one hand, and extracting, selling it and saving the oil proceeds, on the other hand. This arbitrage principle implies that the expected rate of change in marginal oil revenue (net of marginal oil extraction costs) should equal the market rate of interest. The demand for oil together with the total amount of oil reserves then gives the optimal rates of oil extraction, which will be higher if the demand for oil is more elastic. With a declining time path of oil proceeds, the government smoothes tax rates and public spending by saving in line with the wellknown principle of tax smoothing (cf., Barro, 1979). With declining oil revenues, it is also optimal to reinvest all marginal rents from oil production in education, infrastructure, physical capital, sovereign wealth and other productive assets so that the boost to private and public consumption can be sustained as oil revenues dry up (cf., Hartwick, 1977).

The above restates standard wisdom on optimal oil extraction and management of windfall revenues (e.g., Davis et al., 2002; Barnett and Ossowski, 2003; Ossowski et al., 2008; Collier et al., 2009). A major shortcoming of these three fundamental principles of optimal oil extraction and managing the oil proceeds - the Hotelling rule, the tax smoothing principle and the Hartwick rule - is that they fail to take account of stochastic volatility of oil prices, uncertainty about the magnitude of oil reserves, uncertainty about marginal extraction costs, and uncertain economic prospects. The main objective of our paper is to investigate the implications of stochastic oil demand, oil prices, oil reserves and economic prospects on the rates of optimal oil extraction, debt management and the efficient setting of tax rates and public spending when policies are conducted by a prudent government. Although the title seems at first blush an oxymoron, we show that both aggressive oil extraction and precautionary saving are optimal outcomes if prudent policy makers try to hedge against oil price volatility.

To focus on the most relevant issues, we use the starkest model for this purpose. Hence, we adopt a linear two-period model of intertemporal choice for the government allowing for tax collection costs/distortions, endogenous public spending, endogenous private consumption, the dynamics of oil extraction, and price-sensitive demand for oil. Future oil demand, oil reserves and shocks to future private income and government income are uncertain and normally distributed. We suppose quadratic preferences, so that in the absence of prudence the principle of certainty equivalence holds (Theil, 1958) and precautionary saving/borrowing cannot occur as the third derivative of the utility function is zero (Leland, 1968; Sandmo, 1970). To introduce an element of prudence in government extraction and budgetary policies, we use a utility function with constant absolute risk aversion and constant absolute prudence to obtain the certainty-equivalent value of welfare to go (cf., Epstein and Zin, 1989; Weil,

\footnotetext{
${ }^{2}$ Natural resources could be oil, gas, diamonds, silver, gold, copper, bauxite, coffee, etcetera and even foreign aid. For ease of discussion, we use the shorthand 'oil' for all of them.
} 
1993). ${ }^{3}$ We can thus investigate how the Hotelling rule for optimal oil extraction and the tax smoothing principle for optimal debt management and setting of efficient tax rates and public spending have to be modified to allow for prudence.

Our main result is that it is optimal for governments to extract oil more aggressively at the expense of future oil production and to set up precautionary buffers to cope with volatile oil demand and prices, especially if they are more prudent, suffer from oil price volatility, attach a higher priority to the public spending target, and enjoy more monopoly power on the oil market. We also show that cautious governments deliberately under-estimate their oil reserves, which offsets the tendency to extract oil aggressively and reduces the government budget surplus. If governments attach high priority to boosting public spending to its bliss level, prudence implies that they under-predict oil reserves less severely and over-predict future oil prices. This induces more aggressive oil depletion and more government saving. Furthermore, we show that uncertainty about future public revenues or spending needs induces precautionary saving and aggressive oil depletion.

The outline of the paper is as follows. Section 2 sets up the model. Section 3 establishes that certainty equivalence holds and thus that the Hotelling rule for optimal oil extraction and the tax smoothing principle hold in the case of certainty equivalence. Since expected net marginal oil revenue and oil price rise over time, oil revenues decline over time. To deal with declining oil revenue resulting from rising Hotelling scarcity rents, the government runs a surplus in order to smooth taxes and levels of public spending. If current oil demand is high, the country pumps more oil at the expense of future oil production, especially if the shock to oil demand is more persistent, and thus current oil prices and revenues are higher today than in the future which necessitates saving by the government. Section 4 first explains how to obtain analytical results for optimal prudent policy in a linear-quadratic-Gaussian optimal control setup where a constant absolute risk aversion/prudence utility function is used to calculate the certainty equivalent value of expected welfare to go. Section 4 then derives our main result, namely that a prudent government extracts oil reserves aggressively. Sections 5 and 6 analyze what happens with uncertainty about the amount of oil reserves under the ground and about economic prospects, respectively. Section 7 concludes with a summary of our main results and offers some suggestions for further research.

\section{The Model}

To focus on the role of precautionary oil buffers, we employ a two-period framework. We set the interest rate $r \geq 0$ equal to the government's rate of time preference and denote the discount factor by $0<\delta \equiv 1 /(1+r) \leq 1$. The budget deficit at the end of the first period $B$ is the excess of first-period public spending $G_{1}$ over tax revenues $T_{1}$ plus oil revenues $R_{1}$ and the budget surplus at the end of the second

\footnotetext{
${ }^{3}$ This extends the linear-quadratic-Gaussian optimal control framework to allow for constant absolute risk aversion and prudence. Alternatives based on, for example, the linear-exponential-Gaussian framework to analyze precautionary saving are less easy to adopt for our purposes, since we are interested in the intratemporal tradeoff between tax cuts and public spending increases.
} 
period must cover this deficit, $T_{2}+R_{2}-G_{2}-r B=B$, so that the government's intertemporal budget constraint is given by:

$$
B=G_{1}-T_{1}-R_{1}=\delta\left(T_{2}+R_{2}-G_{2}\right),
$$

where $T_{2}, R_{2}$ and $G_{2}$ denote second-period tax revenues, oil revenues and public spending, respectively. The present value of tax plus oil revenues must thus cover the present value of government spending (plus any initial debt, which we assume to be zero). We suppose a linear demand function for oil $N_{t}=\gamma_{D}-\gamma P_{t}+\varepsilon_{t}, \quad t=1,2$, where $N_{t}$ denotes the demand for oil (and equals the volume of oil extraction in absence of storage), $P_{t}$ the oil price, $\varepsilon_{t}$ the normally distributed shock to the demand for oil in period $t, \gamma_{D}>0$ indicates autonomous demand for oil, and $\gamma>0$ the price sensitivity of the demand for oil. We assume that the price elasticity of the demand for oil $\gamma P_{t} / N_{t}$ exceeds unity, so that marginal revenue is positive. ${ }^{4}$ With constant marginal cost of oil extraction $\gamma_{c} \geq 0^{5}$, we write oil revenues (net of extraction costs) in each period as:

$$
\begin{gathered}
R_{1} \equiv\left(P_{1}-\gamma_{C}\right) N_{1}=\left(P_{1}-\gamma_{C}\right)\left(\gamma_{D}-\gamma P_{1}+\varepsilon_{1}\right)=\left(1+\frac{\varepsilon_{1}-N_{1}}{\gamma}\right) N_{1} \text { and } \\
R_{2} \equiv\left(P_{2}-\gamma_{C}\right) N_{2}=\left(P_{2}-\gamma_{C}\right)\left(\gamma_{D}-\gamma P_{2}+\rho \varepsilon_{1}+\varepsilon_{2}\right)=\left(1+\frac{\rho \varepsilon_{1}+\varepsilon_{2}-N_{2}}{\gamma}\right) N_{2} \\
\text { with } \varepsilon_{1}=\Delta \text { and } \varepsilon_{2} \sim \operatorname{IN}\left(0, \sigma^{2}\right),
\end{gathered}
$$

where $\varepsilon_{1}=\Delta$ is the realized shock to current oil demand, $\varepsilon_{2}$ is the normally distributed shock to future oil demand, and the parameter $-1<\rho<1$ indicates the persistence of shocks to oil demand. ${ }^{6}$ Oil demand shocks translate into greater oil price shocks if oil demand is less sensitive to the oil price. Note that we normalize prices so that $\gamma_{P} \equiv\left(\gamma_{D} / \gamma\right)-\gamma_{C}=1 .{ }^{7}$ Oil reserves are exogenous and given by the constant $\bar{N}>0$. We abstract from oil storage, so oil extraction rates satisfy the oil depletion equation:

$$
N_{1}+N_{2}=\bar{N}
$$

Abstracting from private asset accumulation, we assume that private consumption in each period equals

\footnotetext{
${ }^{4} \mathrm{~A}$ ball-park estimate of the price elasticity of world demand for oil is 0.26 , so that with Saudi Arabia controlling $12 \%$ of the global oil market its relevant price elasticity would be $0.26 / 0.12=2.2$ and the corresponding mark-up on marginal extraction cost $86 \%$ (Hamilton, 2008). Less dominant oil exporters control a smaller part of the global market and thus face a higher price elasticity of the demand for their oil.

${ }^{5}$ In practice, oil extraction becomes more expensive as remaining reserves diminish as exploration companies need to go to deeper wells or pump in water or carbon dioxide to maintain pressure.

${ }^{6}$ Empirical evidence suggests that oil prices follow a near random walk and that the current spot price is a better predictor of future oil prices than the forward rate (Hamilton, 2008).

${ }^{7}$ A negative shock to future marginal cost of extraction is thus equivalent to a positive shock to the future oil price.
} 


$$
C_{t}=1-T_{t}-\frac{1}{2} \phi T_{t}^{2}, \quad \phi>0, \quad t=1,2
$$

where $\phi$ indicates the magnitude of the losses from tax collection or production distortions and the undistorted level of production income has been normalized to unity. Social welfare depends on the utility of both private and public consumption:

$$
U \equiv U_{1}+\delta U_{2}, \quad U_{t}=C_{t}-\frac{1}{2} \psi\left(\bar{G}-G_{t}\right)^{2}, \quad \psi>0, \quad t=1,2,
$$

where $\bar{G}>0$ is the bliss level of public spending and $\psi$ the priority attached to attaining the public spending target. Preferences are thus quasi-linear in private consumption.

\section{Certainty-Equivalent Approach: Tax Smoothing and the Hotelling Rule}

The standard procedure is for the government to maximize expected welfare EU subject to (1)-(5). This yields the certainty-equivalent outcome for this linear-quadratic-Gaussian optimal control problem and does not allow for prudence or precaution in the optimal oil extraction, tax and public spending policies of the government. First-period outcomes can thus be obtained from the deterministic control problem with $\varepsilon_{2}$ set to its expected value. Using (1)-(5, the Lagrangian function for this problem is written as:

$$
\begin{gathered}
L \equiv 1-T_{1}-\frac{1}{2} \phi T_{1}^{2}-\frac{1}{2} \psi\left(\bar{G}-G_{1}\right)^{2}+\delta\left[1-\mathrm{ET}_{2}-\frac{1}{2} \phi\left(\mathrm{E} T_{2}\right)^{2}-\frac{1}{2} \psi\left(\bar{G}-\mathrm{EG}_{2}\right)^{2}\right] \\
+\eta\left[\left(1+\frac{\Delta-N_{1}}{\gamma}\right) N_{1}+\delta\left(1+\frac{\rho \Delta-N_{2}}{\gamma}\right) N_{2}+T_{1}+\delta \mathrm{E} T_{2}-G_{1}-\delta \mathrm{E} G_{2}\right]+\mu\left(\bar{N}-N_{1}-N_{2}\right),
\end{gathered}
$$

where $\eta \geq 0$ and $\mu \geq 0$ denote the marginal cost of public funds (i.e., the marginal increase in social welfare from having an extra unit of government financial assets) and the marginal increase in social welfare of an extra unit of oil reserves $N$, respectively.

At the optimum, both the current and the discounted future marginal revenue of oil (net of extraction costs) are set to the marginal value of an extra unit of oil reserves $(\mu / \eta)$. Using $\delta=1 /(1+r)$, we obtain:

$$
1+\frac{\Delta-2 N_{1}}{\gamma}=\frac{1}{1+r}\left(1+\frac{\rho \Delta-2 N_{2}}{\gamma}\right)=\frac{\mu}{\eta} \Rightarrow
$$

$$
N_{1}=\frac{1}{2} \bar{N}+\frac{r}{1+r}\left(\frac{\gamma}{4}\right)+\frac{1-\rho}{4} \Delta \text { and } N_{2}=\frac{1}{2} \bar{N}-\frac{r}{1+r}\left(\frac{\gamma}{4}\right)-\frac{1-\rho}{4} \Delta \text {. }
$$

The first part of (7) corresponds to the Hotelling rule for optimal oil extraction (Hotelling, 1931), which says that the Hotelling scarcity rent - the expected marginal net revenue of oil - should rise at the rate of interest (i.e., $r$ ). The second part of (7) indicates that the path of oil extraction declines, especially fast 
if the rate of interest is high and oil demand is very sensitive to oil prices (high $r$ and $\gamma$ ). The optimal oil extraction path implies the following expected time path for oil prices:

$$
P_{1}=1-\frac{1}{2 \gamma} \bar{N}-\frac{1}{4}\left(\frac{r}{1+r}\right)+\frac{3+\rho}{4 \gamma} \Delta \quad \text { and } \quad \mathrm{E} P_{2}=1-\frac{1}{2 \gamma} \bar{N}+\frac{1}{4}\left(\frac{r}{1+r}\right)+\frac{1+3 \rho}{4 \gamma} \Delta .
$$

Since the Hotelling scarcity rents rise at a rate equal to the rate of interest, oil prices are expected to rise even without temporary oil scarcity (see the third term on the right-hand side of the expressions in (8)). A temporary positive shock to current oil demand (i.e., $\rho=0$ and $\Delta>0$ ) induces the government to pump more oil; future oil production is correspondingly lower. This pushes the current oil price above and the future oil price below its Hotelling path, especially if oil demand is more insensitive to oil prices (low $\gamma$ ). If the shock to current oil demand is permanent (i.e., $\rho=1$ ), the government does not alter its intertemporal pattern of smoothing oil extraction. Consequently, oil prices rise incrementally by the same amount today as in the future (i.e., by $\Delta / \gamma)$. Incremental net revenues from sales of oil today and in the future both increase by the same amount $\frac{1}{2 \gamma} \bar{N} \Delta$ in face of a permanent shock to oil demand $\Delta$, which is higher if oil demand is not very price-sensitive. In contrast, a temporary boom in oil demand induces a temporary rise followed by a decline in oil revenues. In general, net oil revenues are given by:

$$
\begin{aligned}
& R_{1}=\left(1-\frac{1}{2 \gamma} \bar{N}-\frac{1}{4}\left(\frac{r}{1+r}\right)+\frac{3+\rho}{4 \gamma} \Delta\right)\left(\frac{1}{2} \bar{N}+\left(\frac{r}{1+r}\right) \frac{\gamma}{4}+\frac{1-\rho}{4} \Delta\right) \text { and } \\
& \mathrm{ER}_{2}=\left(1-\frac{1}{2 \gamma} \bar{N}+\frac{1}{4}\left(\frac{r}{1+r}\right)+\frac{1+3 \rho}{4 \gamma} \Delta\right)\left(\frac{1}{2} \bar{N}-\left(\frac{r}{1+r}\right) \frac{\gamma}{4}-\frac{1-\rho}{4} \Delta\right)
\end{aligned}
$$

The first-order conditions for the optimal tax rate and level of public spending following from (6) are:

$$
1+\phi \mathrm{T}_{1}=1+\phi \mathrm{ET}_{2}=\psi\left(\bar{G}-G_{1}\right)=\psi\left(\bar{G}-\mathrm{E} G_{2}\right)=\eta
$$

The marginal cost of public funds is thus an increasing function of the tax rate and the demand for public spending in each period is a decreasing function of the cost of public funds. We also note from (10) that it is optimal to set the current tax rate to the expected future tax rate and the current public spending to expected future public spending, which is a straightforward extension of the principle of tax smoothing (Barro, 1979) and follows from the condition that it is optimal to intertemporally smooth the marginal costs of public funds. Upon substitution of (10) into the expected present-value government budget constraint (1), we solve for the optimal marginal cost of funds, tax rates and public spending shortfalls:

$$
\begin{gathered}
\eta=\left(\frac{\psi}{\psi+\phi}\right)\left[1+\phi\left(\bar{G}-R_{P}\right)\right], \quad T_{1}=\mathrm{ET}_{2}=\frac{\psi\left(\bar{G}-R_{P}\right)-1}{\psi+\phi} \\
\text { and } \bar{G}-G_{1}=\bar{G}-\mathrm{E}_{2}=\frac{1+\phi\left(\bar{G}-R_{P}\right)}{\psi+\phi},
\end{gathered}
$$


where $\mathrm{E} R \equiv R_{1}+\delta \mathrm{E} R_{2}$ follows from (9) and is the present value of expected oil revenues (i.e., oil wealth) and $R_{P} \equiv \mathrm{ER} /(1+\delta)$ defines the permanent value of oil revenue or the return on oil wealth under the ground (i.e., the constant value of oil revenue that yields the same present value as the actual stream of oil revenues). Having more oil reserves and thus more oil wealth $E R$ implies a lower cost of public funds, especially if tax collection costs/distortions are significant and the public spending target has high priority (high $\phi$ and $\psi$ ). As a result, the government can afford to cut the tax rate and raise public spending in each period The cut in taxes is relatively large compared to the boost in public spending if tax collection costs and distortions are significant and the weight given to the spending target is small (large $\phi$, small $\psi$ ). A higher target (bliss) level of public spending induces bigger spending and thus a higher marginal cost of public funds and tax rate.

Equation (11) establishes the tax smoothing principle, which states that tax rates and public spending are smoothed over time. This implies that the current and future expected non-oil primary deficit in each period must equal permanent oil revenue or the return on oil wealth under the ground $R_{p}$ :

$$
G_{1}-T_{1}=\mathrm{EG}_{2}-\mathrm{ET}_{2}=R_{P} \equiv \frac{\mathrm{E} R}{1+\delta}>0
$$

The full deficit adds interest payments and subtracts oil revenues. The full deficit must equal the difference between permanent and current oil revenue, which is negative (i.e., the government runs a surplus). Using (9), it can be written as:

$$
\begin{gathered}
B=\frac{\delta}{1+\delta}\left(\mathrm{E}_{2}-R_{1}\right)=R_{P}-R_{1}= \\
-\frac{1}{2}\left(\frac{r}{1+r}\right)\left[\gamma+\frac{1}{2}(1+\rho) \Delta-\bar{N}\right]-\frac{1}{2}(1-\rho)\left[1+\left(\frac{1+\rho}{2 \gamma}\right) \Delta\right] \Delta<0 .
\end{gathered}
$$

The first term on the last right-hand side of (13) indicates that falling oil revenues arising from a declining path of oil production and increasing path of Hotelling scarcity rents must be associated with a government surplus (i.e., $B<0$ as positive prices requires that the term in square brackets must be positive). Furthermore, the second term on the last right-hand side of (13) indicates that temporary positive (negative) shocks to oil demand, i.e., $(1-\rho) \Delta$ positive (negative), require the government to save (borrow) with $B$ negative (positive) in order to smooth tax rates and public spending. Permanent shocks to oil demand do not require such a saving motive, but they do lift up the whole Hotelling path of declining oil revenue and thus require the government to save more (operates via the first term). Once the shock to future oil prices is known, we can calculate the future oil price, future oil revenue, the future tax rate, and the future level of public spending: 


$$
\begin{gathered}
P_{2}=\mathrm{EP}_{2}+\frac{1}{\gamma} \varepsilon_{2}, \quad R_{2}=\left(\mathrm{E} P_{2}+\frac{1}{\gamma} \varepsilon_{2}\right)\left(\frac{1}{2} \bar{N}-\frac{1-\delta}{4} \gamma-\frac{1-\rho}{4} \Delta\right), \\
T_{2}=\mathrm{ET}_{2}-\frac{1}{2}\left(\frac{\psi}{\psi+\phi}\right)\left(\frac{1}{2} \bar{N}-\frac{1-\delta}{4} \gamma-\frac{1-\rho}{4} \Delta\right) \frac{1}{\gamma} \varepsilon_{2} \text { and } \\
G_{2}=\mathrm{E}_{2}+\frac{1}{2}\left(\frac{\phi}{\psi+\phi}\right)\left(\frac{1}{2} \bar{N}-\frac{1-\delta}{4} \gamma-\frac{1-\rho}{4} \Delta\right) \frac{1}{\gamma} \varepsilon_{2} .
\end{gathered}
$$

If oil prices turn out higher (lower) than expected, oil revenues and the non-oil primary deficit turn out higher (lower). Consequently, the tax rate is cut (increased) and public spending increased (reduced).

Proposition 1: Without prudence, the net marginal revenues from oil production must rise at the rate of interest rate. With permanent shocks to oil demand, this Hotelling rule is unaffected. The declining path of oil revenues is simply lifted upwards. With temporary shocks to oil demand, more oil is pumped at the expense of less oil production in the future so that current oil prices rise and future prices fall. The government smoothes tax rates and public spending over time, so the government saves to accommodate for declining oil revenues caused by rising oil scarcity rents and on top of that saves/borrows in case current oil demand is high (low). The primary non-oil deficit in each period must equal the permanent value of current and future oil revenues.

In the remainder of this paper, we abstract from current shocks to oil demand so that we can focus on the implications of volatility of future oil prices in section 4, uncertainty about oil reserves in section 5 , and uncertain economic prospects in section 6 . We therefore set $\Delta=0$ from here onwards.

\section{Prudent Approach to Oil Extraction and Oil Revenue Management}

The linear-quadratic model of optimal oil extraction and fiscal policies has been designed to yield policy outcomes that do not depend on the volatility of oil prices and budgetary shocks or on uncertainty about proven oil reserves. ${ }^{8}$ In practice, governments do not adopt a certainty-equivalent approach. They are prudent and are more concerned with, say, the welfare losses of negative future oil price shocks than the welfare gains from positive future oil price shocks. One way of dealing with this is to have a conservative bird-in-hand approach, which implies that the government only uses the interest of accumulated oil wealth to cut taxes or boost public spending. Future oil revenue derived from oil reserves under the ground thus does not affect the current fiscal stance. We prefer a less ad hoc conservative approach and therefore analyze how the Hotelling rule and the tax smoothing principle exposited in section 2 have to be modified under prudent government preferences.

To allow for prudent preferences, we assume that the government maximizes the following criterion:

\footnotetext{
${ }^{8}$ If quadratic preferences in the model of section 2 are replaced by preferences with a positive/negative third derivative, precautionary saving/borrowing would occur (e.g., Leland, 1968; Sandmo, 1970; Sibley, 1975; Zeldes, 1989; Kimball and Mankiw, 1989; Kimball, 1990).
} 


$$
U_{1}+\delta U_{2}^{C E} \text {, where } U_{2}^{C E} \equiv \mathrm{V}^{-1}\left(\mathrm{EV}\left(U_{2}\right)\right)=U_{1}-\delta\left(\frac{1}{\theta}\right) \ln \left(\mathrm{E} \exp \left(-\theta U_{2}\right)\right)
$$

denotes the certainty-equivalent value of welfare to go. The negative exponential function $\mathrm{V}\left(U_{2}\right)=$ $-\exp \left(-\theta U_{2}\right)$ attaches a greater weight to adverse outcomes than to beneficial outcomes and has a constant coefficient of absolute risk aversion $\theta=-\mathrm{V}^{\prime \prime}\left(U_{2}\right) / \mathrm{V}^{\prime}\left(U_{2}\right)>0 .{ }^{9}$ The parameter $\theta$ also equals the coefficient of absolute prudence $-\mathrm{V}^{\prime \prime}\left(U_{2}\right) / \mathrm{V}^{\prime \prime}\left(U_{2}\right)>0$. Our formulation corresponds to a specific form of Epstein-Zin preferences and can be readily extended to allow for larger horizons (Epstein and Zin, 1989; Weil, 1993). ${ }^{10}$ To obtain the optimal prudent oil extraction paths and budgetary policies, we proceed by backward induction making use of the following lemma.

Lemma: Let $U_{2}=\alpha_{0}+\alpha_{1} \varepsilon_{2}-\frac{1}{2} \alpha_{2} \varepsilon_{2}^{2}$ and $\varepsilon_{2} \sim \mathrm{N}\left(0, \sigma^{2}\right)$, then the certainty-equivalent value of $U_{2}$ equals $U_{2}^{C E} \equiv \mathrm{V}^{-1}\left(\operatorname{EV}\left(U_{2}\right)\right)=\alpha_{0}-\frac{1}{2}\left(\frac{\theta \sigma^{2} \alpha_{1}^{2}}{1-\theta \sigma^{2} \alpha_{2}}\right)+\frac{1}{2 \theta} \ln \left(1-\theta \sigma^{2} \alpha_{2}\right)$ provided that $\theta \sigma^{2} \alpha_{2}<1$. In the limiting case $\theta \rightarrow 0$, we have $U_{2}^{C E} \rightarrow \alpha_{0}-\frac{1}{2} \alpha_{2} \sigma^{2}$.

Proof: The proof makes use of the conjugacy of the normal density function and the exponential function and then completing the squares. We have that

$$
\begin{gathered}
E\left[\exp \left(-\theta U_{2}\right)\right]=\int_{-\infty}^{\infty} \frac{1}{\sqrt{2 \pi \sigma^{2}}} \exp \left(-\frac{1}{2 \sigma^{2}} \varepsilon_{2}{ }^{2}\right) \exp \left(-\theta U_{2}\right) \mathrm{d} \varepsilon_{2} \\
\quad=\int_{-\infty}^{\infty} \frac{1}{\sqrt{2 \pi \sigma^{2}}} \exp \left(-\frac{1}{2 \sigma^{2}} \varepsilon_{2}{ }^{2}-\theta\left[\alpha_{0}+\alpha_{1} \varepsilon_{2}-\frac{1}{2} \alpha_{2} \varepsilon_{2}{ }^{2}\right]\right) \mathrm{d} \varepsilon_{2} \\
\quad=\int_{-\infty}^{\infty} \frac{1}{\sqrt{2 \pi \sigma^{2}}} \exp \left(-\frac{1}{2 \sigma^{2}}\left(1-\theta \sigma^{2} \alpha_{2}\right)\left(\varepsilon_{2}-\varepsilon_{2}^{*}\right)^{2}+K\right) \mathrm{d} \varepsilon_{2},
\end{gathered}
$$

where equating coefficients on $\varepsilon_{2}$ and equating the constants in the last two expressions yields

$$
\varepsilon_{2}^{*}=\frac{-\theta \sigma^{2} \alpha_{1}}{1-\theta \sigma^{2} \alpha_{2}}<0 \text { and } K=-\theta\left(\alpha_{0}-\frac{1}{2} \frac{\theta \sigma^{2} \alpha_{1}^{2}}{1-\theta \sigma^{2} \alpha_{2}}\right)
$$

\footnotetext{
${ }^{9}$ This has some similarity with the theory of disappointment aversion (Gul, 1991; Aizenman, 1998), which introduces caution by assigning a bigger weight to undesirable states of nature.

${ }^{10}$ Alternatively, our framework can be extended to longer planning horizons within the context of prudent risksensitive control with atemporal risk aversion (e.g., Whittle, 1990; van der Ploeg,1993; Bommier, 2006).
} 
Since $\int_{-\infty}^{\infty}\left(\frac{1-\theta \sigma^{2} \alpha_{2}}{2 \pi \sigma^{2}}\right)^{\frac{1}{2}} \exp \left(-\frac{1}{2 \sigma^{2}}\left(1-\theta \sigma^{2} \alpha_{2}\right)\left(\varepsilon_{2}-\varepsilon_{2}{ }^{*}\right)^{2}\right) \mathrm{d} \varepsilon_{2}=1$ must be satisfied for the normal density function, we have $E\left[\exp \left(-\theta U_{2}\right)\right]=\exp (K)\left(1-\theta \sigma^{2} \alpha_{2}\right)^{-\frac{1}{2}}$ and thus

$$
U_{2}^{C E}=-\frac{1}{\theta} \ln \left(\mathrm{E}\left[\exp \left(-\theta U_{2}\right)\right]\right)=\alpha_{0}-\frac{1}{2}\left(\frac{\theta \sigma^{2} \alpha_{1}^{2}}{1-\theta \sigma^{2} \alpha_{2}}\right)+\frac{1}{2 \theta} \ln \left(1-\theta \sigma^{2} \alpha_{2}\right) .
$$

Note that $\lim _{\theta \rightarrow 0} U_{2}^{C E}=\alpha_{0}-\frac{1}{2} \alpha_{2} \sigma^{2}$ from using $\ln \left(1-\theta \sigma^{2} \alpha_{2}\right) \cong-\theta \sigma^{2} \alpha_{2}$ for small $\theta$.

The government thus operates under the assumption that Nature deliberately draws oil price shocks to hurt social welfare. Maximizing the certainty equivalent of welfare to go with respect to the future tax rate and future public spending under the assumption that $\varepsilon_{2}=\varepsilon_{2}{ }^{*}$ then yields the optimal prudent outcomes. The government thus adopts a max-min strategy to hedge against adverse outcomes, especially if the coefficient of absolute prudence $\theta$ is large.

To get a rough idea of the size of the buffer needed to cope with unexpected disturbances to the oil price $\varepsilon_{2}$, an atemporal calculation based on our Lemma with $\alpha_{2}=0$ suggests that the optimal savings rate out of a windfall revenue equals $\Xi v^{2} / 2$, where $\Xi \equiv \theta U_{2}$ is the coefficient of relative risk aversion and $v \equiv \sigma / U_{2}$ the coefficient of variation of oil prices. ${ }^{11}$ Hamilton's (2008) 95\%-confidence interval for predicted real oil prices gives a mean oil price of $\$ 137$ per barrel and a standard deviation of $\$ 37.5$ per barrel, so $v=0.27$ for a period of a quarter. A plausible range for $\Xi$ is 1-2, so it is optimal to save between $3.75 \%$ and $7.5 \%$ of the oil windfall. If the oil bonanza lasts, say $T$ quarters, oil prices are much more unpredictable as the coefficient of variation increases for a T-period-ahead forecast to $v \sqrt{T}$. For an oil bonanza that lasts T quarters, we thus save a fraction $\Xi T v^{2} / 4$ of the oil bonanza in a fund. For a horizon of four years, this implies that between $30 \%$ and $60 \%$ of the oil revenues must be saved.

We now return to the intertemporal analysis of optimal oil extraction, debt management and fiscal policies by applying the prudence framework to the analysis of sections 2 and 3 .

\section{Period 2:}

Applying these insights to our problem of optimal oil extraction and budgetary policies, we solve given the budget deficit at the end of period one $B$, second-period oil extraction $N_{2}=\bar{N}-N_{1}$ and the secondperiod budget constraint $G_{2}=T_{2}+\left(1-\frac{N_{2}-\varepsilon_{2}}{\gamma}\right) N_{2}-(1+r) B$ for the optimal max-min solution:

\footnotetext{
${ }^{11}$ Under disappointment aversion, the magnitude of the optimal buffer stock is proportional to the coefficient of variation of commodity prices. Such first-order effects can lead to much larger buffer stocks (Aizenman, 1998).
} 
(16)

$$
\begin{gathered}
U_{2}^{C E}=\operatorname{Max}_{T_{2}} \operatorname{Min}_{\varepsilon_{2}}\left(1-T_{2}-\frac{1}{2} \phi T_{2}^{2}-\frac{1}{2} \psi\left[\bar{G}-T_{2}-\left(1+\frac{\varepsilon_{2}-N_{2}}{\gamma}\right) N_{2}+(1+r) B\right]^{2}\right) \\
+\frac{1}{2 \theta \sigma^{2}} \varepsilon_{2}{ }^{2}+\frac{1}{2 \theta} \ln \left(1-\theta \sigma^{2} \psi N_{2}^{2} / \gamma^{2}\right)
\end{gathered}
$$

where $\alpha_{2}=\psi N_{2}{ }^{2} / \gamma^{2}$ has been used in the Lemma. The first-order optimality conditions yield:

$$
\begin{gathered}
1+\phi T_{2}=\psi\left(\bar{G}-G_{2}\right) \equiv \eta_{2}>0 \text { and } \\
\varepsilon_{2}^{*}=-\theta \sigma^{2}\left(\frac{N_{2}}{\gamma}\right) \eta_{2}
\end{gathered}
$$

where $\eta_{2}$ is the second-period marginal cost of public funds. Intratemporal smoothing requires that high tax rates are now not only associated with low public spending (see (17a)), but also with bigger deliberate downward biases of future oil prices (see (17b)). We note from (17b) that the government depresses the figure for the future oil price below its expected level more severely if absolute prudence and the volatility of the future oil price are substantial (high $\theta \sigma^{2}$ ), if it has a lot of monopoly power on the oil market (low $\gamma$ ), and if the second-period marginal cost of public funds is high. Furthermore, the figure used for the future oil price in the government budget is lower if future oil extraction is high. Hence, if the government extracts oil aggressively in the first period, it extracts less oil in the future and the potential harm done by volatility oil prices is less. Consequently, the government needs to downplay the budgeted future oil prices less strongly. Upon substitution of (17) into the second-period government budget constraint $G_{2}+(1+r) B=T_{2}+\left(1+\frac{\varepsilon_{2}{ }^{*}-N_{2}}{\gamma}\right) N_{2}$, we can solve for the optimal budgeted second-period marginal cost of public funds and thus for the optimal second-period tax rate, public spending and budgeted downward bias in the future oil price:

$$
\begin{aligned}
& \eta_{2}^{*}=\psi\left(\frac{\phi\left[(\bar{G}+(1+r) B)-\left(1-N_{2} / \gamma\right) N_{2}\right]+1}{\psi+\phi-\theta \sigma^{2} \phi \psi N_{2}^{2} / \gamma^{2}}\right)>0, \\
& T_{2}^{*}=\left(\frac{\psi\left[(\bar{G}+(1+r) B)-\left(1-N_{2} / \gamma\right) N_{2}\right]+\frac{\psi}{\phi}}{\psi+\phi-\theta \sigma^{2} \phi \psi N_{2}^{2} / \gamma^{2}}\right)-\frac{1}{\phi}, \\
& G_{2}^{*}=\bar{G}-\left(\frac{\phi\left[(\bar{G}+(1+r) B)-\left(1-N_{2} / \gamma\right) N_{2}\right]+1}{\psi+\phi-\theta \sigma^{2} \phi \psi N_{2}^{2} / \gamma^{2}}\right) \text { and }
\end{aligned}
$$




$$
\varepsilon_{2}^{*}=-\theta \sigma^{2} \psi \frac{N_{2}}{\gamma}\left(\frac{\phi\left[(\bar{G}+(1+r) B)-\left(1-N_{2} / \gamma\right) N_{2}\right]+1}{\psi+\phi-\theta \sigma^{2} \phi \psi N_{2}^{2} / \gamma^{2}}\right)<0 .
$$

A higher public debt at the end of the first period necessitates a higher tax rate and thus implies a higher cost of public funds, which in turn induces lower public spending. A higher public debt also implies a lower budgeted future oil price. We can see from the denominators in the expressions given in (18) that more prudence (higher $\theta$ ), more volatile oil prices (higher $\sigma^{2}$ ) and bigger remaining oil reserves (higher $\mathrm{N}_{2}$ ) makes these budgetary reactions bigger than in section 3 without prudence. Also, bigger tax collection costs/distortions (high $\phi$ ), a higher priority to the spending target (high $\psi$ ), and more monopoly power on the oil market (lower $\gamma$ ) makes these precautionary budgetary reactions - higher taxes and lower spending - also bigger. More aggressive oil depletion in the first period implies that less

oil reserves are left for the second period, so that second-period oil prices are higher and second-period oil revenues are lower (as the elasticity of demand for oil must exceed unity for a monopolist selling oil on the world market).

Upon substitution of the optimal prudent policies (18) into (16), we get the certainty-equivalent value of welfare to go as a function of inherited government debt $B$ and remaining oil reserves $N_{2}=\bar{N}-N_{1}$ :

$$
U_{2}^{C E}=\Omega\left(B, N_{1}\right)
$$

where $\frac{\partial \Omega}{\partial B}=-(1+r) \eta_{2}<0$ and $\frac{\partial \Omega}{\partial N_{1}}=-\left(1+\frac{\varepsilon_{2}{ }^{*}-2\left(\bar{N}-N_{1}\right)}{\gamma}\right) \eta_{2}+\left(\frac{\sigma^{2} \psi\left(\bar{N}-N_{1}\right) / \gamma^{2}}{1-\theta \sigma^{2} \psi N_{2}^{2} / \gamma^{2}}\right)$ are derived with the aid of the envelope theorem. The second-period marginal cost of public funds indicates the marginal loss in future welfare from an extra unit of inherited public debt. A smaller amount of remaining oil reserves caused by aggressive oil extraction has two effects on the certainty-equivalent value of expected welfare to go. First, it implies that the government has fewer funds to boost private and public consumption and therefore welfare to go will be lower. Second, it exposes the country to less fluctuations in oil revenues which boosts social welfare for a prudent government, especially if prudence is substantial, oil prices are highly volatile, the priority given to the public spending target is high, remaining oil reserves are high and monopoly power on the oil market is substantial. For a prudent government, volatile oil prices thus weaken the incentive to leave oil under the ground.

\section{Period 1:}

We can use (19) to obtain social welfare and to derive the optimal first-period tax rate, government borrowing/saving and oil extraction path by solving the optimization problem:

$$
\operatorname{Max}_{T_{1}, B, N_{1}}\left[1-T_{1}-\frac{1}{2} \phi T_{1}^{2}-\frac{1}{2} \psi\left[\bar{G}-T_{1}-\left(1-\frac{N_{1}}{\gamma}\right) N_{1}-B\right]^{2}+\delta \Omega\left(B, N_{1}\right)\right],
$$


where the first-period government budget constraint $G_{1}=T_{1}+\left(1-N_{1} / \gamma\right) N_{1}+B$ has been used to substitute out $G_{1}$. Making use of (19), the optimality conditions with respect to $T_{1}$ and $B$ yield:

$$
1+\phi T_{1}=\psi\left(\bar{G}-G_{1}\right) \equiv \eta_{1}=\eta_{2}>0
$$

Hence, oil price uncertainty does not affect the principle of smoothing the tax rate, the cost of funds and public spending. Making use of (19) again, the optimality condition with respect to $N_{1}$ can be written as:

$$
\begin{gathered}
2\left(N_{1}-N_{2}\right)=\frac{r}{1+r}\left(\gamma-2 N_{2}\right)+\frac{1}{1+r}\left(\frac{\sigma^{2} \psi N_{2} / \gamma}{\left[1-\theta \sigma^{2} \psi N_{2}^{2} / \gamma^{2}\right] \eta_{2}}-\varepsilon_{2}^{*}\right) \\
>\frac{r}{1+r}\left(\gamma-N_{2}\right)>0 .
\end{gathered}
$$

The first term on the right-hand side of expression (22) indicates that oil extraction follows a declining path due to the rise path of Hotelling scarcity rents. The second term in (22) is new and indicates that volatile oil prices (high $\sigma^{2}$ ) make oil extraction more aggressive. The reason is that this leaves less oil reserves for the future, and thus leaves the country less vulnerable to large fluctuations in future oil prices. Oil extraction is especially aggressive if the government is more prudent (high $\theta$ ), attaches a large priority to the public spending target (high $\psi$ ) and enjoys monopoly power on the oil market demand (low $\gamma$ ). On the other hand, if public funds are scarce (high $\eta_{2}$ ), the government is less willing to depart from the Hotelling principle. Hence, oil extraction is somewhat less aggressive. As a result of pumping more oil today, the government receives relatively more oil revenue today than in the future $\left(R_{1}>E R_{2}\right)$ and thus smoothes private and public consumption by running a fiscal surplus $(B<0)$.

Proposition 2: Future oil price uncertainty induces more aggressive oil depletion than predicted by the Hotelling rule, especially if oil prices are highly volatile and the government is very prudent, attaches more priority to its spending target and has substantial monopoly power on the oil market. To ensure flat expected time profiles of the cost of funds, the tax rate and public spending, the government needs to save and more so if oil prices are more volatile and oil extraction is more upfront in order to ensure that future levels rise in line with current levels of public and private consumption.

\section{Uncertainty about Oil Reserves and Future Oil Prices}

In practice, governments cannot be sure about the exact amount of oil reserves. We therefore examine how this uncertainty affects optimal oil extraction paths and budgetary policies of a prudent policy maker. We do this for the situation where the government cannot influence future oil prices by varying 
its supply to the market and demand shocks thus do not affect oil prices either ( $\gamma$ very large).$^{12}$ Instead, we suppose that the future oil price (net of marginal extraction costs) is normally distributed with unit mean and variance $\sigma_{P}{ }^{2}>0$. We also suppose that oil reserves are normally distributed with mean $\bar{N}>0$ and variance $\sigma_{N}{ }^{2}>0$, so we have: ${ }^{13}$

$$
P_{2} \sim N\left(1, \sigma_{P}^{2}\right) \text { and } N \sim \mathrm{N}\left(\bar{N}, \sigma_{N}^{2}\right)
$$

The second-period max-min strategy for the government follows from the problem:

$$
\begin{gathered}
U_{2}^{C E}=\operatorname{Max}_{T_{2}} \operatorname{Min}_{P_{2}, N} 1-T_{2}-\frac{1}{2} \phi T_{2}{ }^{2}-\frac{1}{2} \psi\left[\bar{G}-T_{2}-P_{2}\left(N-N_{1}\right)+(1+r) B\right]^{2} \\
+\frac{1}{2 \theta \sigma_{P}{ }^{2}}\left(P_{2}-1\right)^{2}+\frac{1}{2 \theta \sigma_{N}{ }^{2}}(N-\bar{N})^{2}+\frac{1}{2 \theta} \ln \left(1-\theta \sigma_{P}{ }^{2} \psi\left(N-N_{1}\right)^{2}\right)+\frac{1}{2 \theta} \ln \left(1-\theta \sigma_{N}{ }^{2} \psi P_{2}{ }^{2}\right) .
\end{gathered}
$$

The optimality condition for the future tax rate and future public spending are given by (17a), but the budgeted shock to the future oil price follows from:

$$
\frac{\partial U_{2}^{C E}}{\partial P_{2}}=\left(N-N_{1}\right) \eta_{2}+\frac{1}{\theta \sigma_{P}^{2}}\left(P_{2}-1\right)-\frac{\sigma_{N}^{2} \psi P_{2}}{1-\theta \sigma_{N}^{2} \psi P_{2}^{2}}=0
$$

The budgeted level of oil reserves follows from the optimality condition:

$$
\frac{\partial U_{2}^{C E}}{\partial N}=P_{2} \eta_{2}+\frac{1}{\theta \sigma_{N}{ }^{2}}(N-\bar{N})-\frac{\sigma_{P}{ }^{2} \psi\left(N-N_{1}\right)}{1-\theta \sigma_{P}^{2} \psi\left(N-N_{1}\right)^{2}}=0 .
$$

These are two nonlinear equations in $P_{2}$ and $N$, but for small $\theta$ the last terms on the right-hand sides of $\left(17 b^{\prime}\right)$ and (24) can be approximated by $-\sigma_{N}{ }^{2} \psi P_{2}$ and $-\sigma_{P}{ }^{2} \psi\left(N-N_{1}\right)$, respectively. Solving the resulting linear equations yields the following solution for $P_{2}$ and $N$ :

$$
\begin{gathered}
P_{2}^{*}=-\theta \sigma_{P}{ }^{2} \eta_{2} \Delta\left(\bar{N}-N_{1}\right)+\left(1-\theta \sigma_{P}{ }^{2} \sigma_{N}{ }^{2} \psi\right) \Delta \text { and } \\
N^{*}-\bar{N}=-\theta \sigma_{N}{ }^{2} \eta_{2} \Delta\left\{1-\sigma_{P}{ }^{2}\left[\theta \eta_{2}+\left(\psi / \eta_{2}\right)\left(1-\theta \sigma_{P}{ }^{2} \sigma_{N}{ }^{2} \psi\right)\right]\left(\bar{N}-N_{1}\right)\right\} \cong \\
-\theta \sigma_{N}{ }^{2} \Delta\left[\eta_{2}-\sigma_{P}{ }^{2} \psi\right]\left(\bar{N}-N_{1}\right),
\end{gathered}
$$

\footnotetext{
${ }^{12}$ In that case, the deterministic or certainty-equivalent outcome with $\theta=0$ is degenerate as oil prices cannot adjust to satisfy the Hotelling rule. However, with stochastic shocks and $\theta>0$, the outcome is well defined. One may interpret our outcomes as the limit as $\gamma$ tends to infinity.

${ }^{13}$ We could allow for a positive covariance $v>0$ between shocks to oil reserves and the future oil price to capture that, if unexpectedly the future oil price is higher than the expected future oil price, less accessible reserves may become more profitable as well, but do not pursue that further here.
} 
where $\Delta \equiv\left[\left(1-\theta \sigma_{P}{ }^{2} \sigma_{N}{ }^{2} \psi\right)^{2}-\theta^{2} \sigma_{P}{ }^{2} \sigma_{N}{ }^{2} \eta_{2}{ }^{2}\right]^{-1} \cong\left(1-2 \theta \sigma_{P}{ }^{2} \sigma_{N}{ }^{2} \psi\right)^{-1} \geq 1$. If public spending targets are not so important and the government is happy to stick with the spending level it has (small $\psi$ ), the second term in (25) is close to the expected value of future oil prices. Wet thus we establish from the first term in (25) that a prudent government deliberately under-estimates future oil prices $\left(P_{2}{ }^{*}<1\right)$, especially if the future marginal cost of public funds, the variance of future oil prices and the remaining stock of oil reserves are high. However, if public spending targets are important and the government has a strong desire to raise spending to its bliss level in the presence of windfalls (large $\psi$ ), the second term in (25) is quite a bit larger than the expected value of future oil prices. This indicates that a government wishing to expand public spending has a tendency to over-predict future oil prices, especially if the government is very cautious and oil reserves and future oil prices are highly uncertain. Such a government wants to err on the safe side and not miss the opportunity of increasing public spending and therefore deliberately is optimistic about future oil prices.

Similarly, the first part of equation (26) indicates that a prudent government deliberately underestimates its oil reserves $\left(N^{*}<\bar{N}\right)$ to be on the safe side, especially if oil reserves are highly uncertain and public funds are scarce. The under-prediction is also larger if the amount of oil in the ground is large, i.e., if there has not been much oil extraction in the past, as then oil price volatility is much more harmful. If the government cares a lot about raising public spending to its bliss level (high $\psi$ ), the second part of (26) shows that the under-estimation of oil reserves will be attenuated, especially if oil prices are highly volatile.

To examine what happens to current oil production levels, we consider the marginal effect of oil extraction on the certainty-equivalent value of welfare to go (19) which is now given by:

$$
\frac{\partial \Omega}{\partial N_{1}}=-P_{2}^{*} \eta_{2}+\left(\frac{\sigma_{P}^{2} \psi\left(N^{*}-N_{1}\right)}{1-\theta \sigma_{P}^{2} \psi\left(N^{*}-N_{1}\right)^{2}}\right) .
$$

If a government does not care much about raising public spending to its bliss level, future oil prices are not too volatile and oil reserves have been much depleted, the second term in (19') is small. In that case, we know from (26) that, as a precaution, the government deliberately under-estimates oil reserves. Since $\partial \Omega / \partial N_{1}<0$, the government then has an incentive to reduce current levels of oil production. Interestingly, this result holds despite the government under-predicting future oil prices (see (25)). Since oil revenues are thus expected to increase over time, the optimal response for the government is to borrow on the capital market $(B>0)$ so that it can smooth private and public consumption.

However, if the government attaches high priority to public spending and wishes to increase it a lot in the presence of windfalls while also oil prices are turbulent enough and remaining oil reserves are substantial (high $\psi$, high $\sigma_{P}{ }^{2}$, low $N_{1}$ ), oil reserves are less likely to be under-predicted, especially if remaining oil reserves are substantial (see (26)), and future oil prices are more likely to be overpredicted. In that case, the government has an incentive to extract oil more aggressively today at the expense of future production. This follows from $\partial \Omega / \partial N_{1}>0$ if the second term in $\left(19^{\prime}\right)$ dominates, 
which confirms that then the result is reversed. The resulting declining path in oil revenues warrants government budget surpluses to make it possible to smooth public and private consumption $(B<0)$.

Proposition 3: With little monopoly power on the oil market, more uncertainty about oil reserves induces a prudent policy maker to under-estimate oil reserves. It therefore extracts oil more slowly than suggested by the Hotelling rule, especially if public funds are scarce. If oil prices are highly volatile, a prudent government also under-predicts future oil prices. Rising paths of oil extraction and oil revenues warrant government borrowing to smooth public and private consumption. However, if the government attaches high priority to increasing public spending to its bliss level, it is prudent to deliberately overpredict future oil prices and under-predict oil reserves less severely. This may induce more aggressive oil depletion, especially if oil prices are very turbulent. In this case, the government accumulates more financial and other non-oil assets than it would have done otherwise so that it can smooth the time paths for the cost of funds as well as those of the tax rate and public spending.

\section{Uncertain Economic Prospects}

Governments also face uncertainty about economic prospects. This will affect future production income and thus private consumption and tax revenues. It would also affect future unemployment benefit bills. We capture this uncertainty by adding a second-period normally distributed shock with zero mean and variance $\sigma_{G}{ }^{2}$ to the government budget constraint (1),

$$
B=G_{1}-T_{1}-R_{1}=\delta\left(T_{2}+\varepsilon_{2}^{G}+R_{2}-G_{2}\right), \quad \varepsilon_{2}^{G} \sim N\left(0, \sigma_{G}{ }^{2}\right) .
$$

Abstracting from uncertainty about oil reserves (i.e., $\sigma_{N}^{2}=0$ ), the second-period max-min problem for a government focusing on oil price volatility and uncertain economic prospects is:

$$
\begin{gathered}
U_{2}^{C E}=\operatorname{Max}_{T_{2}} \operatorname{Min}_{\varepsilon, \varepsilon_{G}} 1-T_{2}-\frac{1}{2} \phi T_{2}^{2}-\frac{1}{2} \psi\left[\bar{G}-T_{2}-\left(1+\frac{\varepsilon_{2}-N_{2}}{\gamma}\right) N_{2}+B-\varepsilon_{2}^{G}\right]^{2} \\
+\frac{1}{2 \theta \sigma^{2}} \varepsilon_{2}^{2}+\frac{1}{2 \theta \sigma_{G}^{2}} \varepsilon_{2}^{G^{2}}+\frac{1}{2 \theta} \ln \left(1-\theta \sigma^{2} \psi \frac{N_{2}^{2}}{\gamma^{2}}\right)+\frac{1}{2 \theta} \ln \left(1-\theta \sigma_{G}{ }^{2} \psi\right)
\end{gathered}
$$

Equation (17) is unaffected. Making use of (19), the second-period budgeted shock to public income follows from the optimality condition:

$$
\frac{\partial U_{2}^{C E}}{\partial \varepsilon_{2}^{G}}=\eta_{2}+\frac{1}{\theta \sigma_{G}{ }^{2}} \varepsilon_{2}^{G}=0 \Rightarrow \varepsilon_{2}^{G^{*}}=-\theta \sigma_{G}{ }^{2} \eta_{2}<0 .
$$

A prudent government deliberately budgets for a negative shock to future revenues (or, equivalently, to a positive shock to the target level of future public spending), especially if the variances of public 
revenue shocks is high and the future cost of public funds is high. Consequently, as a precaution, it sets current tax rates higher and current public spending lower to build up buffer stocks and hedge against possible adverse future economic outcomes. This results in a higher current cost of public funds than the expected future cost of public funds. Inspecting $\partial \Omega / \partial N_{1}$ in (19), we note that the negative term is smaller due to the lower value of $\eta_{2}$ and thus the marginal benefit of aggressive oil extraction is higher. Hence, uncertain economic prospects not only induce prudent budgetary policies but also more aggressive oil extraction; both lead to bigger precautionary buffers to hedge against an uncertain future.

Proposition 4: Uncertainty about future public revenue or spending needs induces precautionary saving, hence a prudent government sets higher taxes and lower spending especially if the variance of budgetary shocks is high and the degree of prudence is large. Over time, tax rates are expected to fall and public spending to rise. By extracting oil more aggressively, the government builds more substantial buffers to hedge more effectively against adverse future shocks to the budget. These buffers are accumulated on top of any buffers needed to cope with oil price volatility.

\section{Concluding Remarks}

We constructed the starkest possible welfare-based model of optimal oil extraction and debt management and optimal setting of tax rates and public spending. The linear-quadratic set-up implies that certainty equivalence holds. Oil extraction must then be governed by the Hotelling rule, so that net marginal revenues from oil production must rise at the rate of interest rate. As a result of this rising path of scarcity rents, oil revenues decline and the government smoothes tax rates and public spending by saving. With positive permanent shocks to oil demand, the Hotelling rule is unaffected but the time path of declining oil revenues is lifted up and the government saves initially more to realize the task of smoothing taxes and spending. With temporary shocks to oil demand, more oil is pumped today at the expense of less future oil production and consequently current oil prices are higher and future prices

lower. To smooth tax rates and public spending over time, the government borrows (saves) if current oil demand is high (low). The primary non-oil deficit in each period must equal the permanent value of current and future oil revenues.

Since oil prices are notoriously volatile, we show how a prudent government would adjust its optimal oil extraction and fiscal policies. The way we introduce prudence is to take a certainty-equivalent value of welfare to go using a utility function with constant absolute degree of risk aversion and prudence. This approach corresponds to a particular form of Epstein and Zin (1989) preferences, which separates risk aversion and intertemporal substitution. We thus show that more volatile oil prices induces more aggressive oil depletion, especially if the government is relatively prudent, attaches more priority to its spending target, and has more monopoly power on the oil market. Since it is optimal for the government to ensure a flat expected time profile for the cost of funds, it must also smooth the tax rate 
and public spending. This requires the government to save some of current oil receipts to provide for future public and private consumption.

If oil reserves are not known exactly and the oil market is fairly competitive, a prudent government deliberately under-estimates oil reserves and also under-predicts future oil prices when oil prices are very turbulent. As a result, oil reserves are depleted more slowly than suggested by the Hotelling rule and the government needs to save less to smooth private and public consumption. However, if the government attaches a big priority to boosting public spending to its bliss level, prudence implies a tendency to under-predict oil reserves less severely and to over-predict oil prices. As a result, there is a tendency to extract oil more aggressively and thus for the government to save more than in a deterministic environment.

Uncertainty about future public revenue or spending needs induces precautionary saving, so that a prudent government must set higher taxes and lower spending especially if the variance of budgetary shocks is high and the degree of prudence is large. Over time, tax rates fall and public spending rise. By extracting oil more aggressively, the government accumulates bigger buffers and hedges more effectively against adverse future shocks to the budget.

Summing up, the government runs a surplus to smooth tax rates and public spending levels to deal with: (i) rising Hotelling scarcity rents and the resulting declining path of oil revenue; (ii) temporary oil price hikes and declining paths of oil revenue resulting from temporary booms in oil demand; (iii) aggressive oil depletion and the resulting decline in oil revenue resulting from hedging against oil price volatility; (iv) aggressive oil depletion occurring for a government that attaches a big priority to boosting public spending to its bliss level and thus over-predict oil prices and under-predicts oil reserves less severely; and $(v)$ precautionary saving to hedge against uncertainty about future fiscal revenues or spending needs. The government runs a deficit if there are temporary falls in oil demand and a rising path of oil revenue (cf., (ii)). The government also saves less or borrows if oil prices are not very volatile and underprediction of reserves is more important than under-prediction of oil prices (cf., (iii)). It also does this if it does not attach a big priority to public spending and thus under-predicts oil reserves, over-predicts oil prices when oil prices are very volatile, and consequently delays oil extraction (cf., (iv)). The first two factors apply also in a deterministic world while the other three factors derive from prudence.

Policy makers also have to cope with uncertainty about geological conditions and discovery of new fields, future costs of oil extraction, future substitutes for oil, oil supplies held by competitors, and sensitivity of market prices with respect to the quantity of oil supplied to the market. A prudent government errs on the safe side with all of these forms of uncertainty as well, especially if shocks are more persistent. If the government faces habit persistence in the sense that public and private agents get hooked on high levels of spending, the government may extract oil more aggressively and accumulate more precautionary buffers to offset this.

Storage of oil, gas, and other commodities imply that Hotelling scarcity rents must rise at the rate of interest plus cost of storage, so that optimal depletion paths will become steeper as well. Study of optimal storage rules and management of commodity stabilization funds such as the Chilean Copper 
Stabilization Fund (e.g., Newbery and Stiglitz, 1991) suggests that even with large risk and low storage costs, the resulting buffer stocks are very small. This is also the case in models where agents are liquidity constrained (Deaton, 1991). However, once one allows for disappointment aversion, the optimal size of buffer stocks is much larger (Aizenman, 1991). An interesting area for further research is therefore to investigate the impact of prudence on optimal storage rules for commodities.

Policy making in developing countries requires one to take account of real-life market failures (Collier et al., 2009; van der Ploeg and Venables, 2009). For example, many developing countries suffer from capital scarcity and are slowly moving towards a steady state with higher levels of income per capita. Building a sovereign wealth fund is then not necessarily optimal. If countries are underdeveloped and the windfall is insufficiently large and protracted, it is better to speed up the development process by using the oil to pay off foreign debt more rapidly, bring down interest rates and boost private and public investment. One must also take account of bottlenecks in productive capacity and other absorption constraints, since in many developing economies productive capacity of the construction and other nontraded sector may be insufficient to allow an efficient and productive hike in public spending on much needed infrastructure. Given that oil bonanzas typically induce appreciations of the real exchange rate (Dutch disease), these constraints are even more likely to bite in the booming construction and other non-traded sectors. Allowing for the notorious volatility of oil and other commodity prices in conjunction with absorption constraints for productive use of government spending, it may pay to save rather more of the proceeds of an oil bonanza in a fund than one would have done otherwise (e.g., Gelb and Grasmann, 2008). Much more research is required on the implications of volatility commodity prices for resource-rich developing economies with capital scarcity and absorption constraints.

Finally, our normative framework of optimal oil extraction and management of oil proceeds with volatile oil prices needs to be extended with political economy considerations. For example, in commodity price booms politicians may lose sight of value for money and invest in white elephants which are difficult to reverse when commodity prices collapse. ${ }^{14}$ These problems may be especially severe if the minister of finance is weak and faces many unsustainable claims from its spending ministers. These common-pool problems can lead to rapacious natural resource depletion and excessive debt accumulation.

Furthermore, prudently accumulated buffer funds can be raided for short-run electoral purposes. ${ }^{15}$ Also, such funds are typically very liquid and can be raided by political rivals with different preferences about

\footnotetext{
${ }^{14}$ Earlier work on white elephants as a credible form of redistribution (Robinson and Torvik, 2003) may be useful.

${ }^{15}$ Shocks to income and the tax base require a prudent government to build precautionary buffers. Such buffers offset the debt biases of the common-pool problem within the cabinet of ministers, but can be raided for opportunistic short-term electoral gains (van der Ploeg, 2009). Various other political economy distortions can also lead to raiding of buffers and thus limit accumulation of such buffers in practice as well (e.g., Tornell and Lane, 1998; Aizenman and Powell, 1998).
} 
spending public goods. ${ }^{16}$ More research is needed on how volatility and political economy affect oil extraction and fiscal policy in more realistic political economy settings.

\section{References}

Aizenman, J. (1998). Buffer stocks and precautionary savings with loss aversion, Journal of International Money and Finance, 17, 931-947.

Aizenman, J, and A. Powell (1998). The political economy of public savings and the role of capital mobility, Journal of Development Economics, 57, 1, 67-95.

Barnett, S. and R. Ossowski (2003). Operational aspects of fiscal policy in oil-producing countries, in J. Davis, R. Ossowski and A. Fedelino (eds.), Fiscal Policy Formulation and Implementation in OilProducing Countries, International Monetary Fund, Washington, D.C.

Barro, R.J. (1979). On the determination of the public debt, Journal of Political Economy, 87, 5, 940971.

Beetsma, R.M.W.J. and F. van der Ploeg (2008). Partisan public investment and debt biases - Liquidity of government assets and the case for fiscal restrictions, mimeo., University of Amsterdam.

Bommier, A. (2006). Uncertain lifetime and intertemporal choice: risk aversion as a rationale for time discounting, International Economic Review, 47, 4, 1223-1236.

Collier, P., F. van der Ploeg, M. Spence and A.J. Venables (2009). Managing resource revenues in developing countries, OxCarre Research Paper No. 2009-15, University of Oxford.

Davis, J., R. Ossowski, J. Daniel and S. Barnett (2002). Stabilization and Savings Funds for Non-Renewable Resources: Experience and Fiscal Policy Implications, IMF Occasional Paper No. 205, International Monetary Fund, Washington, D.C.

Deaton, A. (1991). Saving with liquidity constraints, Econometrica, 59, 1221-1248.

Epstein, L.G. and S.E. Zin (1989). Substitution, risk aversion, and the temporal behavior of consumption and asset returns: a theoretical framework, Econometrica, 57, 4, 937-969.

Gelb, A. and S. Grasmann (2008). Confronting the oil curse, mimeo., World Bank, Washington, D.C.

Gul, F. (1991). A theory of disappointment aversion, Econometrica, 59, 667-686.

Hamilton, J.D. (2008). Understanding crude oil prices, Energy Journal, to appear.

\footnotetext{
${ }^{16}$ With partisan preferences about different types of illiquid public investment projects, incumbent governments over-borrow and over-invest in partisan projects to prevent future investments in pet projects by political rivals and incumbents therefore put fewer resources in liquid sovereign wealth funds (Beetsma and van der Ploeg, 2008).
} 
Hartwick, J.M. (1977). Intergenerational equity and the investing of rents from exhaustible resources, American Economic Review, 67, 5, 972-974.

Hotelling, H. (1931). The economics of exhaustible resources, Journal of Political Economy, 39, 137-175.

Kimball, M.S. (1990). Precautionary saving in the small and in the large, Econometrica, 58, 53-73.

Kimball, M.S. and N.G. Mankiw (1989). Precautionary saving and the timing of taxes, Journal of Political Economy, 97, 863-879.

Leland, H.E. (1968). Saving and uncertainty: the precautionary demand for saving, Quarterly Journal of Economics, 465-473.

Newbery, D. and J. Stiglitz (1981). The Theory of Commodity Price Stabilization, Clarendon Press, Oxford.

Ossowski, R., M. Villafuerte, P.A. Medas and T. Tomas (2008). Managing the Oil Revenue Boom: The Role of Fiscal Institutions, Occasional Paper 260, International Monetary Fund, Washington, D.C.

Ploeg, F. van der (1993). A closed-loop solution for a model of precautionary saving, Review of Economic Studies, 60, 2, 385-396.

Ploeg, F. van der (2009). Political economy of prudent budgetary policy, International Tax and Public Finance, to appear.

Ploeg, F. van der and A.J. Venables (2009). Harnessing windfall revenue: optimal policies for resourcerich developing economies, OxCarre Research Paper 2008-09, University of Oxford.

Robinson, J.A. and R. Torvik (2003). White elephants, Journal of Public Economics, 89, 2-3, 197-210.

Sandmo, A. (1970). The effect of uncertainty on saving decisions, Review of Economic Studies, 353-360.

Sibley, D.S. (1975). Permanent and transitory effects of optimal consumption with wage income uncertainty, Journal of Economic Theory, 68-82.

Theil, H. (1958). Economic Forecasts and Policy, North-Holland, Amsterdam.

Tornell, A. and P.R. Lane (1998). Are windfalls a curse? A non-representative agent model of the current account, Journal of International Economics, 83-112.

Weil, P. (1993). Precautionary saving and the permanent income hypothesis, Review of Economic Studies, 60, 367-383.

Whittle, P. (1990). Risk-Sensitive Optimal Control, John Wiley \& Sons, Chichester.

Zeldes, S.P. (1989). Optimal consumption with stochastic income: deviations from certainty equivalence, Quarterly Journal of Economics, 104, 2, 275-298. 